\title{
Visual impairment and spectacles ownership among upper secondary school students in northwestern China
}

\author{
J Zhao, H Guan *, K Du, H Wang, Matthew Boswell, Y Shi, Scott Rozelle, Nathan Congdon, Annie Osborn
}

\section{A B S T R A C T}

Purpose: To assess the prevalence of visual impairment and spectacles ownership among academic and vocational upper secondary school students in rural China.

Methods: This cross-sectional study included 5583 students from four academic upper secondary schools (AUSSs) and two vocational upper secondary schools (VUSSs) in Mei and Qianyang counties, Baoji Prefecture, Shaanxi Province. In March and April 2016, students underwent assessment of visual acuity (VA) and completed a questionnaire regarding spectacles use and family characteristics. Students with visual impairment (presenting VA $\leq 6 / 12$ in the better eye) and students needing spectacles (uncorrected VA $\leq 6 / 12$ in the better eye, which could be improved to $>6 / 12$ with refraction) were identified.

Results: Among 5583 students (54\% boys, mean age $16.4 \pm 1.0$ years) in grades 10 and grade 11 attending AUSSs $(n=4549)$ and VUSSs $(n=1034)$, visual impairment was detected in 4026 students. Among the AUSS students, 3425 (75\%) needed spectacles; 2551 (75\%) had them. Among the VUSS students, 601 (58\%) needed spectacles; this proportion was significantly smaller $(\mathrm{P}=0.004)$, as was the proportion who had spectacles $(n=212$, $35 \%, \mathrm{P}<0.001)$, compared with the AUSS students. Multivariate analysis showed that ownership of
This article was published on 6 Feb 2020 at www.hkmj.org. male sex $(\mathrm{P}<0.001)$, and residence in an urban area $(\mathrm{P}<0.034)$. Spectacles ownership was also strongly associated with AUSS education $(\mathrm{P}<0.001)$.

Conclusion: There is a high rate of unmet need in visual care among upper secondary school students. Lack of spectacles ownership among children who needed them was significantly associated with VUSS education.
Hong Kong Med J 2020;26:35-43
https://doi.org/10.12809/hkmj197926
${ }^{1} \mathrm{~J}$ Zhao, PhD
${ }^{1} \mathrm{H}$ Guan *, PhD
${ }^{1} \mathrm{~K} \mathrm{Du}, \mathrm{PhD}$
${ }^{2} \mathrm{M}$ Boswell, MA
${ }^{1}$ Y Shi, PhD
${ }^{2} \mathrm{~S}$ Rozelle, PhD
$3,4,5 \mathrm{~N}$ Congdon, $\mathrm{MD}$
${ }^{1}$ A Osborn, BA
${ }^{2} \mathrm{H}$ Wang, $\mathrm{PhD}$
Center for Experimental Economics in Education, Shaanxi Normal University, Xi'an, China
2 Freeman Spogli Institute for International Studies, Stanford University, Stanford, California, United States
${ }^{3}$ Centre for Public Health, Queen's University Belfast, Belfast, United Kingdom
Orbis International, New York, United States
${ }^{5}$ Zhongshan Ophthalmic Center, Guangzhou, China

\section{New knowledge added by this study}

- This study investigated the prevalence of refractive error and rate of spectacles ownership among 5583 students in academic upper secondary schools (AUSSs) and vocational upper secondary schools (VUSSs) in northwestern rural China.

- Visual impairment was observed in 4026 students, of whom 3425 were in AUSSs (75\%) and 601 were in VUSSs (58\%). Of these 4026 students, 2763 were observed to own spectacles. Among the 2763 students who owned spectacles, 2551 of those were in AUSSs (75\%) and 212 were VUSSs (35\%).

- Among students who needed spectacles, a larger proportion of students in VUSSs did not own spectacles, compared with students in AUSSs.

Implications for clinical practice or policy

- There is a high rate of unmet need in visual care among upper secondary school students in rural northwestern China.

- China's health and education policymakers should consider incorporating programmes that specifically address spectacles ownership and quality among rural upper secondary schools, especially among those attending vocational upper secondary schools and those with low socio-economic status. 


\section{中國西北農村地區高中生視力損傷及眼鏡 擁有率分析}

\author{
趙錦、關宏宇、杜康、王歡、包偉明、史耀疆、羅斯高、 \\ 康南、熊安妮
}

目的：了解中國西北農村地區普通高中和職業高中學生的視力損傷及 眼鏡擁有率。

方法：該研究以陝西省寶雞市眉縣、千陽縣四所普通高中和兩所職業 高中5583名學生為研究對象。2016年3月至2016年4月期間, 研究人 員對所有樣本學生進行視力測試, 完成有關眼鏡使用率和學生家庭基 本特徵的問卷調查。通過視力測試準確識別出視力損傷的學生 (較好 眼的視力 $\leq 6 / 12$ ) 和須戴眼鏡的學生 (較好眼的未嬌正視力 $\leq 6 / 12$, 經 矯正［配戴眼鏡］視力 $>6 / 12)$ 。

結果：普通高中 $(n=4549)$ 和職業高中 $(n=1034) 10$ 年級和 11 年級 的5583名樣本學生中（54\%為男生，平均年齡 $16.4 \pm 1.0$ 歲），4026名 學生患有視力損傷。普通高中學生中, 3425 人 $(75 \%)$ 須戴眼鏡, 其 中 2551 人 $(75 \%)$ 擁有眼鏡。職業高中學生中, 僅601人（58\%）須戴 眼鏡; 與普通高中學生相比, 職業高中學生須戴眼鏡 $(\mathrm{P}=0.004)$ 和 擁有眼鏡的比例（ $\mathrm{n}=212 ， 35 \%, \mathrm{P}<0.001)$ 明顯較低。多元迴歸分析 結果顯示, 學生是否擁有眼鏡與更嚴重的未矯正視力（ $(P<0.001 ）$

男性 $(\mathrm{P}<0.001)$ 和城市戶口 $(\mathrm{P}<0.034)$ 顯著相關。眼鏡擁有率與其 接受普通高中教育密切相關 $(\mathrm{P}<0.001)$

結論：中國西北農村地區高中生患有視力損傷的比例較高, 學生眼鏡 擁有率低與其接受職業高中教育顯著相關。

\section{Introduction}

Half of all children with vision problems worldwide reside in China, ${ }^{1}$ and many children in rural China are visually impaired. In particular, a recent study of vision problems among primary school children in rural northwestern China showed that $24 \%$ of 9 - to 11-year-old students in grades 4 and 5 of primary school had myopia. ${ }^{2}$ Among 13- to 15-year-old students in lower secondary school, half $(50.4 \%)$ of all students reportedly exhibit visual impairment. ${ }^{3}$ Other studies have shown similarly high rates of myopia among children in rural China. ${ }^{4,5}$

Children with poor vision experience academic difficulty, such that poor vision is significantly negatively correlated with academic performance. ${ }^{2}$ Appropriate spectacles wear has been shown to increase the capacity and motivation of students to learn. In two recent randomised controlled trials in China, students who were provided free spectacles demonstrated statistically significant improvement in academic performance., 3 Although spectacles enable non-invasive, inexpensive treatment of myopia, a significant proportion of rural Chinese children who need spectacles do not own them. ${ }^{6}$ In a sample of 18915 students in grades 4 to 6 in rural Gansu Province, $>97 \%$ of near-sighted students did not own spectacles. ${ }^{7}$ Among 9- to 11-yearold students in primary school, as few as one in six students with poor uncorrected vision owned spectacles. ${ }^{2}$ In lower secondary school, only $37 \%$ of students who needed spectacles were observed to own spectacles.

In addition to the outright failure to own spectacles, under-correction or the use of poorly fitted spectacles (including spectacles with refractive inaccuracy and spectacles that were not upgraded in a timely manner) may increase the burden of children with poor vision due to refractive error. ${ }^{6}$ Researchers have discovered high rates of inaccuracy in spectacles prescriptions in rural China. In a random sample of 3226 children in 15 middle schools (grades 7-10) in Guangdong Province, nearly $67 \%$ of student-owned spectacles were inaccurate. A spectacles quality-check study conducted in 33 primary schools in Shaanxi and 36 primary schools in Gansu showed that nearly half $(46 \%)$ of students with spectacles had a Snellen visual acuity (VA) that was not corrected to $\geq 6 / 12.8,9$

An understanding of vision problems among rural students in elementary and lower secondary schools is beginning to emerge in the literature; however, to the best of our knowledge, few studies have examined visual impairment and spectacles ownership among the approximately 13.5 million upper secondary school (grades 10-12) students in rural China. Empirical studies regarding spectacles quality among these students are similarly scarce. As a result, factors determining spectacles ownership and quality at this age are poorly understood. Vision problems among upper secondary school students are of particular concern in rural China because visual impairment has been shown to increase as students age through the school system; notably lower secondary school students experience higher rates of impairment and uncorrected poor vision, compared with primary school students..$^{10}$ Therefore, there may be a greater need for quality vision care among upper secondary school students.

Furthermore, these vision problems among students in rural China are of particular concern because of China's two-track upper secondary school system. Specifically, there are two types of upper secondary schools, academic upper secondary schools (AUSSs) and vocational upper secondary schools (VUSSs). Empirical studies comparing AUSS and VUSS students in China have shown that VUSS attendance does not lead to gains in specific skills and that it reduces general skills (relative to AUSS attendance). Moreover, VUSS students have a higher tendency to drop out. ${ }^{11}$ The primary determinant of whether a student attends an AUSS or a VUSS is that student's performance on an entrance exam. Given that uncorrected vision in primary and middle school can lead to reduced academic performance, ${ }^{3,7}$ students without spectacles or with incorrect prescriptions may be attending VUSSs at higher rates than are consistent with their abilities. There 
may also exist a feedback mechanism between the skills VUSS students are likely to learn and the rates of spectacles ownership, as well as the quality of spectacles, among these students. In particular, high rates of uncorrected refractive error could mean that VUSS students experience smaller benefits from school than AUSS students; this might cause students (or their parents) to have less interest in spectacles. However, without empirical studies to assess potential links between spectacles ownership and quality in both AUSS and VUSS, there is no basis to study causal mechanisms. Understanding differences in vision and access to quality vision care in China's upper secondary school environment can help to support future studies of this issue.

The overall objective of this study was to assess the prevalence of visual impairment, rate of spectacles ownership, and quality of spectacles among upper secondary school students in northwestern rural China. To fulfil this objective, there were three specific aims. First, the prevalence of refractive error, rate of spectacles ownership, and quality of spectacles were assessed in both AUSS and VUSS students. Second, the factors associated with spectacles ownership were assessed among students who had refractive errors. Finally, the association between spectacles ownership and type of upper secondary school (AUSS or VUSS) was investigated.

\section{Methods}

The protocol for this study was approved in full by Institutional Review Boards at Stanford University, Palo Alto, US, and the Zhongshan Ophthalmic Center, Guangzhou, China. Permission was received from the local Board of Education in each county, as well as the principals of all schools involved. The principles of the Declaration of Helsinki were followed throughout.

\section{Setting}

This study was carried out in Mei and Qianyang counties, both of which are located within Baoji prefecture in the southern part of Shaanxi Province. The Shaanxi Province per capita gross domestic product (GDP) was $\$ 7728$ in $2015 .{ }^{12}$ Baoji prefecture ranked approximately in the middle of all prefectures within Shaanxi Province (ranked 4/10 at $\$ 7651$ per year). ${ }^{13}$ The per capita GDP in Baoji prefecture is similar to the per capita GDP in Shaanxi Province. In terms of per capita GDP, Mei county and Qianyang county ranked approximately in the middle of all counties in Shaanxi Province (Mei county ranked $44 / 107$ at $\$ 5667$ per year, while Qianyang county ranked $55 / 107$ at $\$ 5272$ per year) ${ }^{13}$; therefore, the per capita GDPs of these two counties are relatively similar to the per capita GDP of Shaanxi Province (\$7728). The per capita GDPs in these two counties are similar to the per capita GDPs in
Ningxia Autonomous Region (\$6210) and Qinghai Province (\$5845). ${ }^{14}$ In addition to its average GDP, our sample area is broadly representative of poorer rural parts of northwestern China due to the scarcity of agricultural resources (cultivated land per capita of only 0.11 hectares per household, similar to the regional average). ${ }^{12}$

\section{Data collection}

Data for this study were collected in Mei county during March 2016, and in Qianyang county during April 2016. The study was conducted at all six upper secondary schools in Mei and Qianyang counties, including four AUSSs (3 in Mei county and 1 in Qianyang county) and two VUSSs (1 in each county). Total enrolment for the six schools was 5583 students; 4549 attended AUSSs and 1034 attended VUSSs. Access to these schools for research purposes was granted by the Board of Education of each county. All students in all grades 10 and 11 in each sample county and sample school participated in the data collection process.

Data were collected in two parts by enumerators, graduate students from Shaanxi Normal University who had been trained by optometrist from the Zhongshan Ophthalmic Center. In the first part of the data collection effort, enumerators administered a questionnaire to all students, regarding a number of student and household characteristics. The variables that were created from the data included spectacles ownership (defined as the ability to produce spectacles at school on the day the questionnaire was administered, following prior instructions to bring them that day), grade level, sex, urban or rural residence, school type, boarding status at school, parental migration status (both parents worked away from home this semester), and parental educational level. In the second part of the data collection effort, the survey team conducted a VA test to measure the sharpness of each student's vision. Visual acuity was measured without refractive correction for all children, as well as with habitually worn correction for children who owned spectacles. The data collection procedure is shown in the Figure.

\section{Visual acuity assessment}

The VA assessment was conducted using Early Treatment in Diabetic Retinopathy Study Tumbling-E charts (Precision Vision, La Salle [IL], US). The chart has 14 rows of optotypes (represented by a capital letter E) with five optotypes pointing randomly in different directions in each row. The sizes of the optotypes become smaller with vertical movement downward on the chart. Visual acuity is recorded as $6 / \mathrm{X}$, such that X varies between 60 (at the top of the chart) and 3 (at the bottom of the chart) when tested at a distance of $4 \mathrm{~m}$. 
5583 Initial vision screening

4549 Academic upper secondary school (82\%)

I034 Vocational upper secondary school (19\%)
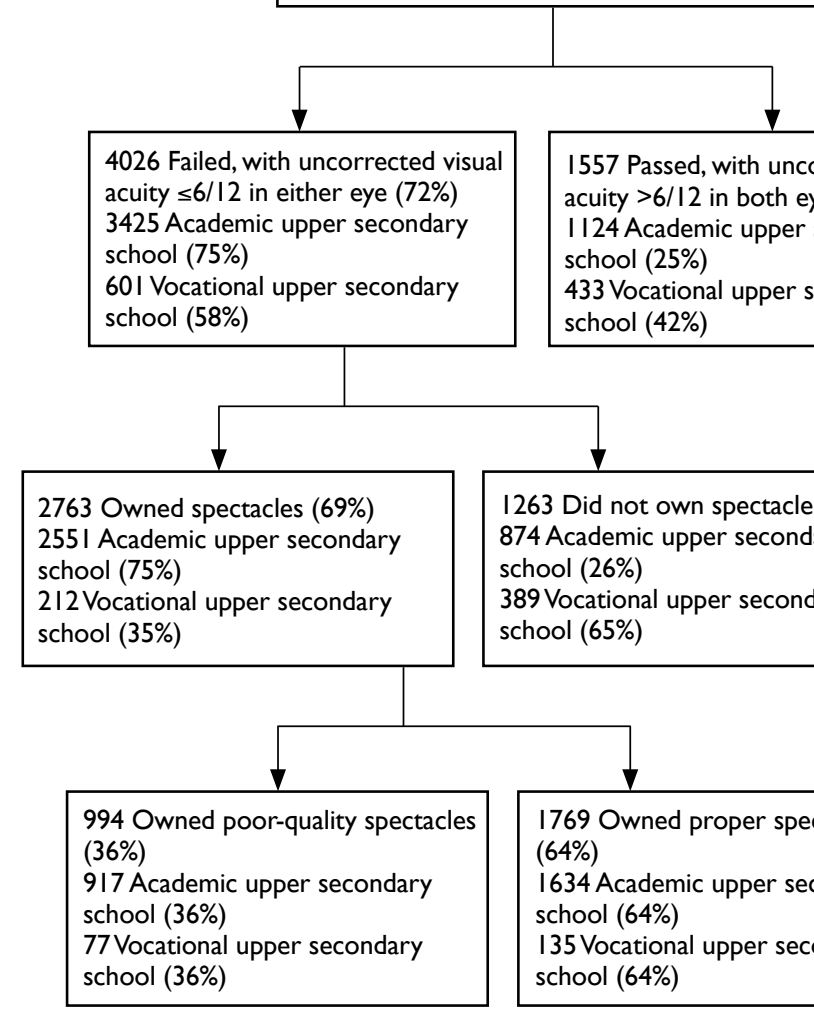

FIG. Flowchart of participants in this study
We also performed a subgroup analysis of students with poor vision, which was defined as uncorrected VA $\leq 6 / 12$ in the better eye. The definition of visual impairment in the better eye included only binocular visual impairment. Using the VA of the better eye as a cut-off for poor vision is a common practice in clinical vision research, because the VA of the better-seeing eye is the best indication of an individual's level of vision. ${ }^{4,6,15}$ We stratified poor vision into mild poor vision (presenting $\mathrm{VA} \leq 6 / 12$ to $6 / 18$ ), moderate poor vision (presenting VA $<6 / 18$ to $6 / 60$ ), and severe poor vision (presenting VA $<6 / 60$ ), in accordance with categories proposed in the World Health Organization International Statistical Classification of Disease 10th Revision. ${ }^{2}$

To calculate and compare different VA levels in this study, we used a linear scale with constant increments, $\log$ MAR (logarithm of the minimum angle of resolution). ${ }^{2} \log$ MAR is one of the most commonly used continuous scales to describe VA, and uses the logarithm transformation: logMAR $=\log _{10}(1 / \mathrm{VA}) \cdot \log \mathrm{MAR}$ offers a relatively intuitive interpretation of VA measurement. Its scale uses constant increments of 0.1 , where each increment indicates approximately one line of VA loss in the Early Treatment in Diabetic Retinopathy Study chart. Higher logMAR values indicate worse VA. ${ }^{2}$

\section{Statistical methods}

We first conducted a general descriptive analysis of visual impairment, spectacles ownership, and spectacles quality. We also investigated the prevalence of various baseline variables among students attending AUSSs and those attending VUSSs. Variables included logMAR VA, level of poor vision (ie, mild, moderate, or severe), school type (AUSS $=1$ ), age, grade (grade 10=1), sex $($ male $=1)$, boarding status (living at school=1), residence (urban $=1$ ), parental migration status (both migrated $=1$ ), and parental education for both mother and father (completed $\geq 12$ years of education $=1$ ).

Next, to explore potential factors influencing spectacles ownership, we investigated all baseline variables as predictors of ownership among students who needed spectacles, using simple and multiple logistic regression analyses. We included only students with uncorrected VA $\leq 6 / 12$ in either eye in our regression analyses. To explore the relationship between spectacles ownership and the type of upper secondary school (AUSS or VUSS), we employed a second logistic regression analysis method, which controlled for VA, age, sex, urban or rural residence, parental migration status, and parental education levels; this analysis included only students with uncorrected VA $\leq 6 / 12$ in either eye. All analyses were performed using Stata version 14.0 statistical software (StataCorp, College Station [TX], US). All tests were two-sided and $\mathrm{P}<0.05$ was considered statistically significant. 


\section{Results}

Among the 5583 students (54\% boys, mean age $16.4 \pm 1.0$ years) in grades 10 and grade 11 at four AUSSs $(n=4549)$ and two VUSSs $(n=1034), 100 \%$ completed both the questionnaire and the vision screening. Uncorrected VA of $\leq 6 / 12$ was present in 4026 students (72\%); of these, 3425 were in AUSSs (75\% of AUSS students) and 601 were in VUSSs (58\% of VUSS students). A greater proportion of AUSS students had poor vision, compared with VUSS students $(\mathrm{P}=0.004$, Table 1$)$.

Among students with poor uncorrected vision, 2763 (69\%) demonstrated owning spectacles. Of the students who owned spectacles, 2551 were in AUSSs (75\% of students with poor vision attending AUSSs) and 212 were in VUSSs (35\% of students with poor vision attending VUSSs). Among students who needed spectacles, a greater proportion of students in VUSSs did not own spectacles, compared with students in AUSSs (Table 2).

When spectacles ownership was stratified by severity of visual impairment in the better eye, $72 \%$ of students with mild poor vision (726/1009) in AUSSs and $32 \%$ of students with mild poor vision (61/190) in VUSSs had spectacles. Of students with moderate poor vision, 95\% (1148/1207) in AUSSs and 63\% (95/152) in VUSSs had spectacles. Finally, of students with severe poor vision, 99\% (461/468) in AUSSs and $90 \%(35 / 39)$ in VUSSs had spectacles (Table 2). The spectacles owned by the students were often undercorrected or exhibited refractive inaccuracy; $36 \%$ of students who had spectacles failed the VA screening while wearing their spectacles. Both AUSS and VUSS students who had spectacles were equally likely to have under-corrected vision (Table 2).

Simple logistic regression models for predicting spectacles ownership revealed that the following characteristics were significant predictors among students with poor vision (Table 3): worse uncorrected VA $(\mathrm{P}<0.001)$; AUSS attendance $(\mathrm{P}<0.001)$; a lower grade level $(\mathrm{P}=0.006)$; male sex $(\mathrm{P}<0.001)$; boarding at school $(\mathrm{P}=0.001)$; residence in an urban area $(\mathrm{P}=0.001)$; and both parents outmigrated for work $(\mathrm{P}=0.015)$. Students whose mothers had completed at least 12 years of education were also more likely to own spectacles than students whose mothers did not finish upper secondary school $(\mathrm{P}=0.006)$; similarly, students whose fathers completed at least 12 years of education were more likely to own spectacles $(\mathrm{P}=0.020)$.

TABLE I. Comparison of baseline characteristics between students attending academic upper secondary school and those attending vocational upper secondary school*

\begin{tabular}{|c|c|c|c|c|}
\hline Characteristics $†$ & All $(n=5583)$ & $\begin{array}{c}\text { AUSS ( } \mathrm{n}=4549 \\
81.5 \%)\end{array}$ & $\begin{array}{c}\text { VUSS }(n=1034 \\
18.5 \%)\end{array}$ & $\begin{array}{l}\text { P value (AUSS } \\
\text { vs VUSS) }\end{array}$ \\
\hline \multicolumn{5}{|l|}{ Student characteristics } \\
\hline $\begin{array}{l}\text { Visual acuity of better eye (logMAR) [Snellen } \\
\text { equivalent] }\end{array}$ & $0.42 \pm 0.39[6 / 15]$ & $0.46 \pm 0.39[6 / 19]$ & $0.27 \pm 0.35[6 / 12]$ & 0.023 \\
\hline $\begin{array}{l}\text { Students who failed vision screening } \\
\text { (uncorrected visual acuity } \leq 6 / 12 \text { in either eye) }\end{array}$ & $4026(72.1 \%)$ & $3425(75.3 \%)$ & $601(58.1 \%)$ & 0.004 \\
\hline Age & $16.4 \pm 0.96$ & $16.4 \pm 0.96$ & $16.5 \pm 0.95$ & \\
\hline$\leq 16$ years & $3119(55.9 \%)$ & $2566(56.4 \%)$ & $553(53.4 \%)$ & 0.646 \\
\hline$>16$ years & $2411(43.2 \%)$ & $1936(42.6 \%)$ & $475(45.9 \%)$ & \\
\hline Grade 10 students & $2892(51.8 \%)$ & $2315(50.9 \%)$ & $577(55.8 \%)$ & 0.358 \\
\hline Male sex & 3009 (53.9\%) & $2352(51.7 \%)$ & $657(63.5 \%)$ & $<0.001$ \\
\hline Boarding at school & $4567(81.8 \%)$ & $3692(81.2 \%)$ & $875(84.6 \%)$ & 0.837 \\
\hline Rural residence & $4688(84.0 \%)$ & $3725(81.9 \%)$ & $963(93.1 \%)$ & 0.044 \\
\hline \multicolumn{5}{|l|}{ Parental and family characteristics } \\
\hline Both parents outmigrated for work & $548(9.8 \%)$ & $431(9.5 \%)$ & $117(11.3 \%)$ & 0.369 \\
\hline \multicolumn{5}{|l|}{ Mother's education level } \\
\hline Did not complete high school & $4233(75.8 \%)$ & $3383(74.4 \%)$ & $850(82.2 \%)$ & 0.095 \\
\hline$\geq 12$ years of schooling & $1243(22.3 \%)$ & $1083(23.8 \%)$ & $160(15.5 \%)$ & \\
\hline \multicolumn{5}{|l|}{ Father's education level } \\
\hline Did not complete high school & $3802(68.1 \%)$ & $2990(65.7 \%)$ & $812(78.5 \%)$ & 0.001 \\
\hline$\geq 12$ years of schooling & 1693 (30.3\%) & $1488(32.7 \%)$ & 205 (19.8\%) & \\
\hline
\end{tabular}

Abbreviations: AUSS = academic upper secondary school; logMAR = logarithm of the minimum angle of resolution; SD = standard deviation; VUSS = vocational upper secondary school

* Data are shown as mean \pm SD or No. (\%) of participants, unless otherwise specified

† Missing values include 'Age' (All 53, AUSS 47, VUSS 6), 'Mother's education level' (All I07, AUSS 83, VUSS 24), and 'Father's education level' (All 88, AUSS 7I,VUSS 17) 
TABLE 2. Comparison of overall spectacles ownership and ownership of under-corrected or inaccurate spectacles between students attending academic upper secondary school and those attending vocational upper secondary school*

\begin{tabular}{|c|c|c|c|c|c|}
\hline & \multicolumn{5}{|c|}{ Ratios of children who owned spectacles compared with children needing spectacles $†$} \\
\hline & All & AUSS & Vuss & OR $(95 \% \mathrm{Cl})$ & P value \\
\hline $\begin{array}{l}\text { Students who failed vision screening } \\
\text { (uncorrected VA } \leq 6 / 12 \text { in either eye) }\end{array}$ & $2763 / 4026(68.6 \%)$ & $2551 / 3425(74.5 \%)$ & $212 / 601(35.3 \%)$ & $5.36(3.37-8.52)$ & $<0.001$ \\
\hline $\begin{array}{l}\text { Students with poor vision (uncorrected VA } \\
\leq 6 / 12 \text { in the better eye) } \ddagger\end{array}$ & $2526 / 3065(82.4 \%)$ & $2335 / 2684(87.0 \%)$ & $191 / 381(50.1 \%)$ & & \\
\hline Mild (VA $\leq 6 / 12$ to $6 / 18)$ & $787 / 1199(65.6 \%)$ & $726 / 1009(72.0 \%)$ & $61 / 190(32.1 \%)$ & $7.46(1.53-31.1)$ & 0.013 \\
\hline Moderate $(<6 / 18$ to $6 / 60)$ & $1243 / 1359(91.5 \%)$ & $1148 / 1207(95.1 \%)$ & $95 / 152(62.5 \%)$ & & \\
\hline \multirow[t]{3}{*}{ Severe $(<6 / 60)$} & 496/507 (97.8\%) & $461 / 468(98.5 \%)$ & $35 / 39(89.7 \%)$ & & \\
\hline & \multicolumn{5}{|c|}{$\begin{array}{c}\text { Ratios of children who owned under-corrected or inaccurate spectacles compared with } \\
\text { children who owned spectacles§ }\end{array}$} \\
\hline & All & AUSS & VUSS & OR $(95 \% \mathrm{Cl})$ & $P$ value \\
\hline $\begin{array}{l}\text { Students who failed vision screening } \\
\text { (uncorrected VA } \leq 6 / 12 \text { in either eye) }\end{array}$ & $994 / 2763$ (36.0\%) & $917 / 2551(35.9 \%)$ & $77 / 212(36.3 \%)$ & $0.96(0.73-1.27)$ & 0.796 \\
\hline $\begin{array}{l}\text { Students with poor vision (uncorrected VA } \\
\leq 6 / 12 \text { in the better eye) }\end{array}$ & $951 / 2526(37.6 \%)$ & $879 / 2335(37.6 \%)$ & 72/191 (37.7\%) & & \\
\hline Mild (VA $\leq 6 / 12$ to $6 / 18)$ & 185/787 (23.5\%) & $174 / 726(24.0 \%)$ & $11 / 61(18.0 \%)$ & $0.79(0.37-1.64)$ & 0.606 \\
\hline Moderate $(<6 / 18$ to $6 / 60)$ & $518 / 1243(41.7 \%)$ & $477 / 1148(41.6 \%)$ & $41 / 95(43.2 \%)$ & & \\
\hline Severe $(<6 / 60)$ & $248 / 496$ (50.0\%) & $228 / 461$ (49.5\%) & $20 / 35(57.1 \%)$ & & \\
\hline
\end{tabular}

Abbreviations: $95 \% \mathrm{Cl}=95 \%$ confidence interval; AUSS = academic upper secondary school; OR = odds ratios; $\mathrm{VA}$ = visual acuity; VUSS = vocational upper secondary school

* Data are shown as No. (\%) of respondents, unless otherwise specified

$\dagger$ Children who owned spectacles were defined as those who brought spectacles to school on the day the questionnaire was administered, following prior instructions to bring them that day. Children needing spectacles were defined as those with uncorrectedVA $\leq 6 / 12$ in either eye

¥ Mild poor vision was defined as VA $<6 / 12$ but $\geq 6 / 24$ in the better eye; moderate poor vision was defined as VA $<6 / 24$ but $\geq 6 / 48$ in the better eye; severe poor vision was defined as $V A<6 / 48$ in the better eye

$\S$ Poor-quality spectacles were defined as those that did not improve $V A$ to $\geq 6 / 12$ in either eye (insufficient correction)

TABLE 3. Logistic regression model of potential predictors of spectacles ownership among 4026 students needing spectacles*

\begin{tabular}{|c|c|c|c|c|c|c|}
\hline \multirow[t]{3}{*}{ Dependent variable } & \multicolumn{6}{|c|}{ Spectacles ownership } \\
\hline & \multicolumn{3}{|c|}{ Simple logistic model $(n=4026)$} & \multicolumn{3}{|c|}{ Multiple logistic model $(n=4026)$} \\
\hline & Odds ratio & $\begin{array}{c}95 \% \text { confidence } \\
\text { interval }\end{array}$ & $P$ value & Odds ratio & $\begin{array}{c}95 \% \text { confidence } \\
\text { interval }\end{array}$ & $P$ value \\
\hline \multicolumn{7}{|l|}{ Student characteristics } \\
\hline Uncorrected visual acuity (logMAR) & 274.57 & $192.10-392.43$ & $<0.001$ & 386.55 & $258.99-576.94$ & $<0.001$ \\
\hline $\begin{array}{l}\text { Academic upper secondary school attendance } \\
(1=\text { Yes; } 0=\text { No) }\end{array}$ & 5.36 & $4.45-6.43$ & $<0.001$ & 6.39 & $5.01-8.16$ & $<0.001$ \\
\hline Age (years) & 0.98 & $0.91-1.05$ & 0.580 & 0.99 & $0.89-1.09$ & 0.805 \\
\hline Grade 10 (1=Yes; 0=No) & 0.83 & $0.73-0.95$ & 0.006 & & & \\
\hline Male sex $(1=$ Yes; $0=$ No $)$ & 0.71 & $0.63-0.82$ & $<0.001$ & 0.69 & $0.57-0.83$ & $<0.001$ \\
\hline Boarding at school ( $1=$ Yes; $0=$ No) & 0.75 & $0.63-0.89$ & 0.001 & 0.90 & $0.70-1.15$ & 0.411 \\
\hline Residence in an urban area ( $1=$ Yes; $0=$ No) & 1.51 & $1.25-1.81$ & 0.001 & 1.36 & $1.02-1.79$ & 0.034 \\
\hline \multicolumn{7}{|l|}{ Parental and family characteristics } \\
\hline Both parents out-migrated for work ( $1=\mathrm{Yes} ; 0=\mathrm{No})$ & 0.77 & $0.62-0.95$ & 0.015 & 0.86 & $0.64-1.15$ & 0.312 \\
\hline $\begin{array}{l}\text { Mother completed } \geq 12 \text { years of schooling }(1=\text { Yes; } \\
0=\mathrm{No} \text { ) }\end{array}$ & 1.25 & $1.07-1.48$ & 0.006 & 1.04 & $0.81-1.34$ & 0.739 \\
\hline $\begin{array}{l}\text { Father completed } \geq 12 \text { years of schooling }(1=\text { Yes; } \\
0=\mathrm{No} \text { ) }\end{array}$ & 1.19 & $1.08-1.51$ & 0.020 & 1.04 & $0.83-1.30$ & 0.741 \\
\hline
\end{tabular}

Abbreviation: logMAR = logarithm of the minimum angle of resolution

* Logistic regression was used with adjustment for the cluster effect within schools 
Multiple logistic regression analysis revealed that the following characteristics were associated with spectacles ownership: worse uncorrected VA $(\mathrm{P}<0.001)$; AUSS attendance $(\mathrm{P}<0.001)$; male sex $(\mathrm{P}<0.001)$; and residence in an urban area $(\mathrm{P}=0.034)$. In this model, age, boarding status, parental out-migration, and education status were not associated with spectacles ownership (Table 3). In the multiple logistic regression model investigating the relationship between spectacles ownership and type of upper secondary school, spectacles wear was strongly associated with AUSS attendance $(\mathrm{P}<0.001)$; the same result was obtained when controlling for student characteristics and parental characteristics (Table 4).

\section{Discussion}

Our study found a high prevalence of poor vision among upper secondary school students in rural northwestern China: nearly $72 \%$ of these students had refractive errors, which was consistent with the results of a prior analysis in which a high prevalence of poor vision was found among upper secondary school students in rural areas..$^{15}$ Furthermore, rates of correction were well below poor vision prevalence rates: overall, $31 \%$ of students who needed spectacles were not wearing them in this rural northwestern Chinese cohort.

Furthermore, nearly $40 \%$ of the students who wore spectacles had prescriptions with undercorrection or refractive inaccuracy. Thus, nearly half of students with poor vision and more than one third of all students are attending school without clear vision. This demonstrates a high rate of unmet need in visual care among upper secondary school students, which is consistent with the findings of studies from primary and lower secondary schools in rural northwestern China. ${ }^{2,6,16}$

Based on our results, we suspect that several factors may contribute to the low rates of spectacles ownership among rural upper secondary school students. In particular, rates of spectacles ownership were higher in students with worse uncorrected VA, which suggests that students with mild poor vision do not experience a need to correct their vision; these students or their parents may mistakenly presume that spectacles are unnecessary or associated with deteriorations in eyesight. ${ }^{17}$

Another factor that may affect spectacles ownership is a family's level of income/wealth. Spectacles ownership rates were higher among students residing in urban areas, as well as among students with better-educated fathers. These factors may act as proxies for family wealth ${ }^{18,19}$; thus, our results suggest that children in a wealthier family are more likely to wear spectacles when needed. Rural students tend to be much poorer than their urban counterparts, which may explain why many do not own spectacles. Our findings are consistent with those found in the literature. ${ }^{2,9}$

Our results also showed that spectacles ownership was strongly associated with AUSS attendance. This finding implies involvement of several factors in spectacles ownership. One of these factors may be the expectations of academic

TABLE 4. Logistic regression model of spectacles ownership and type of upper secondary school among 4026 students needing spectacles*

\begin{tabular}{|c|c|c|c|c|c|c|}
\hline \multirow[t]{3}{*}{ Dependent variables } & \multicolumn{6}{|c|}{ Type of upper secondary school (AUSS=1, VUSS=0) } \\
\hline & \multicolumn{3}{|c|}{ Simple logistic model } & \multicolumn{3}{|c|}{ Multiple logistic model } \\
\hline & Odds ratio & $\begin{array}{l}\text { 95\% confidence } \\
\text { interval }\end{array}$ & $P$ value & Odds ratio & $\begin{array}{l}\text { 95\% confidence } \\
\text { interval }\end{array}$ & $P$ value \\
\hline Spectacles ownership & 5.36 & $4.45-6.44$ & $<0.001$ & 6.35 & $4.97-8.11$ & $<0.001$ \\
\hline \multicolumn{7}{|l|}{ Student characteristics } \\
\hline Uncorrected visual acuity (logMAR) & & & & 0.59 & $0.41-0.87$ & $<0.001$ \\
\hline Age (years) & & & & 0.96 & $0.87-1.06$ & 0.405 \\
\hline Male sex (1=Yes; $0=$ No) & & & & 0.79 & $0.65-0.95$ & 0.014 \\
\hline Residence in an urban area ( $1=\mathrm{Yes} ; 0=\mathrm{No})$ & & & & 1.75 & $1.25-2.43$ & $<0.001$ \\
\hline \multicolumn{7}{|l|}{ Parental and family characteristics } \\
\hline Both parents out-migrated for work ( $1=\mathrm{Yes} ; 0=\mathrm{No})$ & & & & 0.93 & $0.69-1.25$ & 0.628 \\
\hline $\begin{array}{l}\text { Mother completed } \geq 12 \text { years of schooling ( } 1=\text { Yes; } \\
0=\text { No) }\end{array}$ & & & & 1.13 & $0.86-1.47$ & 0.389 \\
\hline $\begin{array}{l}\text { Father completed } \geq 12 \text { years of schooling }(1=\text { Yes; } \\
0=\text { No) }\end{array}$ & & & & 1.42 & $1.12-1.81$ & 0.004 \\
\hline
\end{tabular}

Abbreviations: AUSS = academic upper secondary school; logMAR = logarithm of the minimum angle of resolution; VUSS = vocational upper secondary school

* Logistic regression was used with adjustment for the cluster effect within schools 
performance for VUSS students, who have lower rates of spectacles ownership than their AUSS peers; VUSS students may have a lighter academic burden, ${ }^{20}$ which allows them to tolerate poorer vision. Their parents may also presume that they do not need spectacles. Moreover, the number of VUSS students with poor vision may also contribute to lowered academic achievements and expectations. Our results are only correlative, but future studies of causal mechanisms are needed. Furthermore, given that VUSS graduates have poorer general skills compared with AUSS graduates, ${ }^{20}$ VUSS students comprise an at-risk population that urgently requires additional investigation.

The overall implication of the study, similar to the findings in studies of primary school and lower secondary school, ${ }^{2,3,5}$ is that systematic implementation of vision care programmes is needed in rural Chinese schools, including upper secondary schools. There is a need to more clearly identify which students exhibit poor vision, as well as a need for programmes that provide spectacles or encourage spectacles wear among affected students. Finally, there is a need for programmes that provide high-quality spectacles.

This study was limited in three ways. First, the results were based on cross-sectional data, such that it was difficult to perform a causal analysis between spectacles ownership and upper secondary school educational choice. Second, data regarding school performance and spectacles ownership were not collected when students were in lower secondary school (prior to AUSS or VUSS attendance); these data might have been useful in a causal analysis. Therefore, we cannot exclude the possibility that factors specific to AUSSs (for instance, more homework leading to less time spent outdoors) might place AUSS students at greater risk of visual impairment. Furthermore, we cannot exclude the possibility that inability to afford spectacles and the lack of spectacles use prior to taking the entrance exam would result in lower overall learning, which would partially contribute to the type of upper secondary school attended; this contribution may lead to a positive correlation between VUSS attendance and poor vision. Third, the participants in this study were recruited from two counties in rural northwestern China, which limits the external validity of the findings.

Despite these limitations, we believe the results from this study provide compelling evidence that a number of students in rural northwestern China are not receiving adequate vision care: poorer students whose parents have less education are less likely to have spectacles when needed; VUSS students are also less likely to have spectacles when needed, compared with AUSS students. We presume that these findings will aid programme planners in targeting vulnerable populations when formulating strategies to reduce the burden of uncorrected myopia in rural China. China's health and education policymakers should consider incorporating programmes that specifically address spectacles ownership and quality in rural upper secondary schools, especially among VUSS students and poorer students.

\section{Author contributions}

All authors contributed to the study, approved the final version for publication, and take responsibility for its accuracy and integrity.

Concept or design: All authors.

Acquisition of data: J Zhao, H Guan, K Du, Y Shi.

Analysis or interpretation of data: J Zhao, H Guan, K Du, Y Shi.

Drafting of the article: J Zhao, H Guan, H Wang, M Boswell, A Osborn.

Critical revision for important intellectual content: H Wang, M Boswell, S Rozelle, N Congdon.

\section{Conflicts of interest}

All authors have disclosed no conflicts of interest.

\section{Funding/support}

This study was supported by the 111 Project (Grant No. B16031). H Guan is funded by the National Natural Science Foundation of China, grant number 7180310.

\section{Ethics approval}

This study was approved by the institutional review board at Stanford University, Palo Alto, United States (Ref 52514). Permission was received from local boards of education in each region and the principals of all schools. A letter was given to children and the parents informing them of the vision screening of their child, and a receipt returned to the school to show the parent consent. The presented data are anonymised, and the risk of identification is low. This study was performed in accordance with the principles of the Declaration of Helsinki.

\section{References}

1. Resnikoff S, Pasolini D, Mariotti SP, Pokharel GP. Global magnitude of visual impairment caused by uncorrected refractive errors in 2004. Bull World Health Organ 2008;86:63-70.

2. Yi H, Zhang L, Ma X, et al. Poor vision among China's rural primary school students: prevalence, correlates and consequences. China Econ Rev 2015;33:247-62.

3. Nie J, Pang X, Sylvia S, Wang L, Rozelle S. Seeing is believing: experimental evidence on the impact of eyeglasses on academic performance, aspirations and dropout among junior high school students in rural China. Econ Dev Cult Change 2018. Available from: https://www. journals.uchicago.edu/doi/10.1086/700631. Accessed 12 Dec 2019.

4. He M, Zeng J, Liu Y, Xu J, Pokharel GP, Ellwein LB. Refractive error and visual impairment in urban children in Southern China. Invest Ophthalmol Vis Sci 2004;45:793-9. 5. Ma X, Zhou Z, Yi H, et al. Effect of providing free glasses 
on children's educational outcomes in China: cluster randomized controlled trial. BMJ 2014;349:g5740.

6. Congdon N, Wang Y, Song Y, et al. Visual disability, visual function, and myopia among rural Chinese secondary school children: the Xichang Pediatric Refractive Error Study (X-PRES)-Report 1. Invest Ophthalmol Vis Sci 2008;49:2888-94.

7. Glewwe P, Park A, Zhao M. A better vision for development: eyeglasses and academic performance in rural primary schools in China. J Dev Econ 2016;122:170-82.

8. Zhang M, Lv H, Gao Y, et al. Visual morbidity due to inaccurate spectacles among school children in rural China: the See Well to Learn Well Project, report 1. Invest Ophthalmol Vis Sci 2009;50:2011-7.

9. Zhou Z, Zeng J, Ma X, et al. Accuracy of rural refractionists in western China. Invest Ophthalmol Vis Sci 2014;55:15461.

10. Ma Y, Congdon N, Shi Y, et al. Effect of a local vision care center on eyeglasses use and school performance in rural China: a cluster randomized clinical trial. JAMA Ophthalmol 2018;136:731-7.

11. Yi H, Li G, Li L, et al. Assessing the quality of uppersecondary vocational education and training: evidence from China. Comp Educ Rev 2018;62:199-230.

12. China Statistics Press. Shaanxi Statistical Yearbook 2015. Available from: http://www.shaanxitj.gov.cn/upload/2016/ tongiinianj/2015/indexch.htm. Accessed 20 Jan 2016.

13. Baoji Statistical Yearbook 2015. Available from: http://tjj. baoji.gov.cn/plus/list.php?tid=32\&TotalResult=135\&Page $\mathrm{No}=3$. Accessed 22 Sep 2017.

14. National Bureau of Statistics, PRC government. China Statistical Yearbook 2015. Available from: http://data.stats. gov.cn/easyquery.htm?cn=E0103. Accessed 9 Jan 2017.

15. He M, Huang W, Zheng Y, Huang L, Ellwein LB. Refractive error and visual impairment in school children in rural southern China. Ophthalmology 2007;114:374-82.

16. Wang X, Yi H, Lu L, et al. Population prevalence of need for spectacles and spectacle ownership among urban migrant children in eastern China. JAMA Ophthalmol 2015;133:1399-406.

17. Sharma A, Congdon N, Patel M, Gilbert C. School-based approaches to the correction of refractive error in children. Surv Ophthalmol 2012;57:272-83.

18. Sutherland D, Yao S. Income inequality in China over 30 years of reforms. Camb J Reg Econ Soc 2011;4:91-105.

19. Eccles JS. Influences of parents' education on their children's educational attainments: the role of parent and child perceptions. Lond Rev Educ 2005;3:191-204.

20. Loyalka PK, Huang X, Zhang L, et al. The impact of vocational schooling on human capital development in developing countries: evidence from China. World Bank Econ Rev 2016;30:143-70. 